\title{
Cervical Artery Dissection is Associated with Widened Aortic Root Diameter
}

\author{
Vladimir Skljarevski, Michele Turek, and Antoine M. Hakim
}

\begin{abstract}
Objective: Dissection of the internal carotid and vertebral arteries is a well recognized cause of stroke, especially in the middle-aged. The exact etiology of this condition is controversial. According to one theory there is an underlying vasculopathy originating from disturbed development of the neural crest. The neural crest gives rise to several tissues, including the tunica media of large cervical arteries and the outflow tract of the heart. We attempted to test the theory that developmental abnormality at the level of the neural crest may play a role in dissection of the large cervical arteries. Methods: We designed a retrospective case control study. By means of transthoracic echocardiography we measured the aortic root diameter in a group of patients with radiographically determined dissection of at least one large artery in the neck. The results were compared to a control group. Results: In comparison to age matched controls, male patients were found to have a significantly larger aortic root. Although a similar trend was apparent in females, the difference between the patient and control group of females was not statistically significant. Conclusions: Patients with cervical artery dissections may have other abnormalities in organs arising from the neural crest. A larger prospective clinical study and further research are needed to establish a firm link between dissection of the cervical arteries and abnormalities in other organs.
\end{abstract}

RÉSUMÉ: La dissection des artères cervicales est associée à un plus grand diamètre de l'origine de l'aorte. Objectif: La dissection de la carotide interne et des artères vertébrales est une cause bien connue d'accident vasculaire cérébral, surtout dans la population d'âge moyen. L'étiologie exacte de cette condition est controversée. Une hypothèse propose qu'il existe une vasculopathie sous-jacente suite à un développement anormal de la crête neurale. La crête neurale donne naissance à plusieurs tissus, incluant la media des grosses artères cervicales et aux voies de chasse du coeur. Nous avons tenté de vérifier l'hypothèse selon laquelle une anomalie du développement au niveau de la crête neurale pourrait jouer un rôle dans la dissection des artères cervicales de gros calibre. Méthodes: Il s'agit d'une étude cas/témoins. Nous avons mesuré, au moyen de l'échocardiographie transthoracique, le diamètre de l'origine de l'aorte chez un groupe de patients ayant une dissection prouvée radiologiquement d'au moins une artère du cou de gros calibre. Les résultats ont été comparés à ceux obtenus chez un groupe contrôle. Résultats: Dans le groupe expérimental d'hommes, l'origine de l'aorte était significativement plus large que dans le groupe contrôle apparié pour l'âge. Bien qu'une tendance était évidente chez les femmes, la différence entre le groupe expérimental et le groupe témoin n'était pas significative. Conclusions: Il est possible que les patients qui ont une dissection d'une artère cervicale aient également d'autres anomalies des organes qui proviennent de la crête neurale. Une étude prospective de plus grande envergure et des recherches plus poussées seront nécessaires pour établir un lien entre la dissection des artères cervicales et des anomalies d'autres organes.

Can. J. Neurol. Sci. 1998; 25: 315-319

Arterial dissection is a term applied to the phenomenon of cleavage along the layers of a blood vessel wall with consequent formation of clot within the wall itself. Dissections most commonly occur in the large arteries such as the aorta and its main branches. Large cervical arteries are affected less often while dissections of intracranial arteries are rare. In a large hospital only 1-3 vertebral dissections are diagnosed yearly. ${ }^{1,2}$ Carotid dissections are somewhat more common with an annual incidence rate of $2.5-3.0$ per $100,000 .^{3-5}$ Some authors believe that dissections are rather underdiagnosed in routine clinical practice and that they may cause up to 22 percent of strokes in young adults. ${ }^{6}$ Cervical artery dissections are multiple in 28 percent of cases with a recurrence rate of one percent per year. ${ }^{7}$

The etiology and pathogenesis of this condition are not clear. Classically, dissection was thought to be caused by hypertension and trauma or neck torsion, but the real contribution of these factors is unknown. It has also been suggested that certain inherited connective tissue disorders (Ehlers-Danlos, Marfan syndrome, alpha-1-antitrypsin deficiency, osteogenesis imperfecta, fibromuscular dysplasia) make affected people prone to dissections, ${ }^{8}$ yet most patients with dissections have no signs of generalized connective tissue disorder and many of them have no history of preceding neck trauma.

From the Divisions of Neurology (V.S., A.M.H.) and Cardiology (M.T.), Ottawa Hospital-General Site. University of Ottawa, Ottawa.

RECEIVED SEPTEMBER 25, 1997. ACCEPTED IN FINAL FORM JULY 14, 1998.

Reprint requests to: A.M. Hakim, Division of Neurology, Ottawa Hospital-General Site, 501 Smyth Road, Ottawa, Ontario, Canada K1H 8L6 
It has been posited that dissection starts with an intimal tear. ${ }^{9}$ In fact, pathological findings after a dissection include a tear in the arterial intima that spreads through the vessel wall creating a plane of dissection within the tunica media and, subsequently, forming a blood-filled pseudo lumen. The pseudo lumen may contain clot and may either expand and occlude the true lumen of the vessel or disrupt the innermost layer (intima) of the vessel and release clot into the main bloodstream. Rarely, the enlarging pseudo lumen may disrupt the entire arterial wall and cause an overt haemorrhage. ${ }^{5}$ Microscopic studies commonly reveal lesions like cystic necrosis and disorganized fibres in the tunica media of affected arteries. ${ }^{10,11}$

More recent studies have searched for, and some have suggested the existence of, a more widespread disorder underlying artery dissection. A subtle disorder in connective tissue metabolism was suggested, ${ }^{12,13}$ and the discovery of familial cases of artery dissections ${ }^{14-16}$ led to several studies which unsuccessfully aimed to find a responsible gene(s). ${ }^{17}$ On the other hand, an increased incidence of bicuspid aortic valve in cases of familial dissections, an increased incidence of congenital heart disease in those with sporadic dissections, ${ }^{14,18}$ and skin lentigines in several family members suffering arterial dissections, ${ }^{15}$ lead to the suggestion that a neural crest defect may underlie at least some cases of arterial dissection.

In an attempt to test the hypothesis that arterial dissection arises from a "cristopathy", or abnormality in neural crest development, we have looked for an association between cervical arterial dissection and aortic root dilation. We limited our search to the aortic root in patients with radiographically proven dissection largely because of its accessibility to echocardiography. Despite the small groups of patients we were able to identify who satisfied all our entry and exclusion criteria, we showed a statistically significant association between cervical artery dissection and a wider aortic root, at least in men. Our data suggest that cervical artery dissection may be part of a wider syndrome.

\section{Methods and Patients}

The study was designed as a retrospective case control evaluation of the association between clinically proven arterial dissection and the size of the aortic root. Using a computerized database at the Ottawa General Hospital (OGH) we identified patients whose discharge diagnosis was coded as artery dissection and who were treated either in the neurology or neurosurgery services. The period covered by the search was January 1993 - March 1997 inclusive. Upon identifying all the patients with carotid or vertebral artery dissection, verified by angiography and/or MRI/MRA, those who had transthoracic echocardiography (TTE) as part of their stroke work-up were selected. The transthoracic method of measurement is an acceptable standard for aortic root assessment. ${ }^{19}$ This method was also used in the present study because transesophageal echocardiography is not done routinely in all our stroke patients, whereas TTE is, and TTE has been used in previous studies of aortic root pathology. ${ }^{20,21}$ Their charts were then reviewed for a history of high blood pressure or other conditions which may be associated with aortic root dilatation (coarctation of aorta, aortic dissection, heart surgery). Those found to have such a condition were excluded. The remaining patients formed an experimental group whose aortic root diameter on echocardiogram was recorded.
Echocardiographic measurements were obtained with a commercially available ultrasound machine (HP 77020A; HewlettPackard Co., Andover, Mass.) with a $2.5 \mathrm{MHZ}$ phased array imaging transducer. Patients were imaged in the left lateral semirecumbent position. Aortic root measurements were acquired on-line in either the parasternal short or long axis views in the standard fashion according to ASE (American Society of Echocardiography) guidelines from M-mode tracings guided by two-dimensional imaging.

A control group of patients was selected from asymptomatic, normotensive patients who had been referred for an echocardiogram when a heart murmur had been heard by their physicians, but we ascertained by TTE that they were free of any structural heart abnormalities that could cause aortic root dilatation, such as valve disease, before they were included in the control group. The control and experimental groups were age and sex matched. The size of the aortic root is also affected by body size (height and weight). We do not have data on body size as this is not routinely collected for echo studies, but in a subset of patients where this information was available there was no statistical difference in body size.

Since we were testing if the aortic root diameter was larger in patients with arterial dissection, the difference in aortic root diameter between the experimental and control groups was tested by a single tail t-test. The threshold of significance was set at $\mathrm{p}=0.05$.

\section{RESULTS}

During the study period of 51 months, 49 patients were discharged from the OH-GS with a diagnosis of dissection of either the carotid or vertebral arteries. Twenty of these had a transthoracic echocardiogram done as a part of the stroke workup. Four of these twenty patients were eliminated for purposes of this study: two because of a history of high blood pressure, and two because they were being treated with antihypertensive drugs. The remaining 16 patients were 7 men and 9 women, ranging in age from 41 to 64 years (mean 51.9) and 29 to 68 years (mean 42.6), respectively. There was no significant difference between the experimental and control groups with regards to age. Four males and 3 females were diagnosed with vertebral artery dissection, while the rest had internal carotid artery dissections. Four patients had a history of mild neck trauma. In eight cases the diagnosis was confirmed by both MRI/MRA and four-vessel angiography, six had an MRI/MRA only, and the remaining two had formal angiography. Figure 1 shows a selected example of dissection evident on angiography. The results of aortic root measurements in the experimental and control groups are summarized for men and women separately (Tables 1 and 2). A representative echocardiogram is seen in Figure 2. The difference in aortic root diameter between the experimental and control groups of males was significant (single tail t-test $p=0.0128$ ). The same statistical test in the female groups revealed a $p$ value of 0.0727 .

\section{Discussion}

Cervical artery dissection remains a puzzle. The patient usually presents with complaints of dull pain in the neck along the course of the affected vessel, and the clinical signs are often 


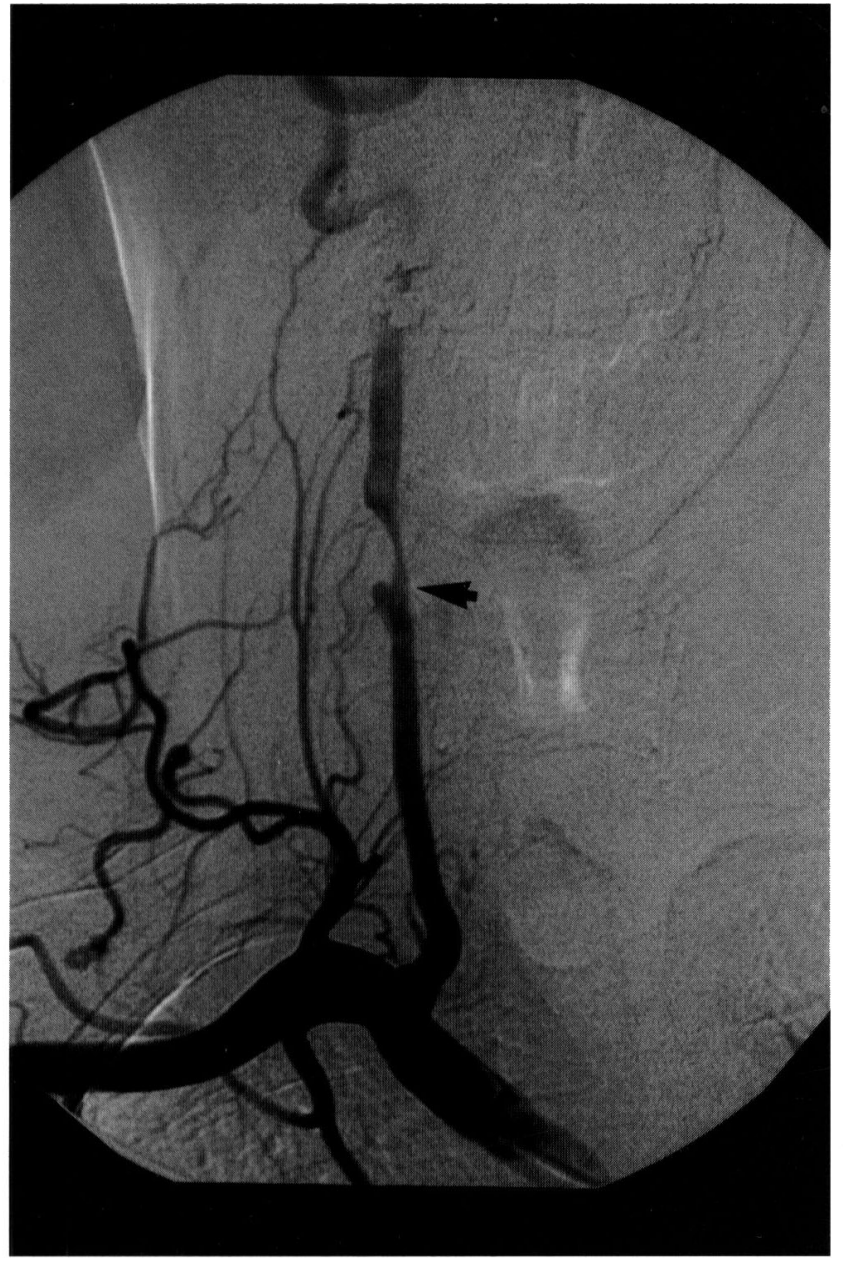

Figure 1: A selected example of a right vertebral artery dissection diagnosed by angiography (arrow).

those of a stroke. The natural history of the condition is rather favourable: $85 \%$ of patients recover completely, and mortality is under $5 \% .^{5}$ Dissection of the intracranial portions of the carotid and vertebral arteries is a rare and more ominous condition with considerably worse prognosis..$^{9,22-27}$

Despite the relatively benign natural history of this condition, urgent medical attention is required. The diagnosis is confirmed by contrast angiography, ${ }^{2,11,28}$ but increasingly magnetic resonance angiography ${ }^{29,30}$ and even duplex Doppler ultrasound are useful in detection of dissections of the large lumen vessels. ${ }^{29,31}$ The goal of medical treatment is to prevent the complications of embolization from the clot formed within the wall of the affected artery, or rupture of the arterial wall due to enlarging hematoma. Anticoagulation followed by antiplatelet therapy is recommended..$^{5,32}$

The favourable outcome of most large arterial dissections belies our ignorance about the specific etiology in most cases. When trauma is suspected as the cause, it is often so minor as to raise the question why many more individuals exposed to the same trauma suffer no complications. An attempt at confirming a connective tissue disorder or collagen vascular disease in specific cases is usually fruitless. For these reasons, the suggestion
Table 1: Aortic root diameter in two groups of males.

\begin{tabular}{ccclcl}
\hline & \multicolumn{2}{c}{ Experimental group } & \multicolumn{2}{c}{ Control group } \\
\hline & Age & Dissection & $\begin{array}{l}\text { Aortic root } \\
\text { diameter, cm }\end{array}$ & Age & $\begin{array}{l}\text { Aortic } \\
\text { root diameter, cm }\end{array}$ \\
\hline 1. & 52 & ICA & 3.8 & 62 & 2.9 \\
2. & 50 & ICA & 3.8 & 49 & 3.1 \\
3. & 41 & ICA & 3.6 & 54 & 3.3 \\
4. & 64 & VA & 3.0 & 52 & 3.1 \\
5. & 55 & VA & 3.1 & 41 & 3.1 \\
6 & 52 & VA & 3.9 & 55 & 3.4 \\
7. & 49 & VA & 3.7 & 47 & 3.0 \\
8. & & & & 47 & 3.1 \\
9. & & & & 56 & 2.9 \\
10. & & & & 45 & 2.8 \\
\hline Mean & $\mathbf{5 1 . 9}$ & & $\mathbf{3 . 4 4 3 ^ { * }}$ & $\mathbf{5 0 . 8}$ & $\mathbf{3 . 0 7 0 ^ { * }}$ \\
SD & $\mathbf{6 . 9}$ & & $\mathbf{0 . 4 2 8}$ & $\mathbf{6 . 2}$ & $\mathbf{0 . 1 8 3}$ \\
\hline
\end{tabular}

*Single tail t-test: $\mathrm{p}=0.0128$

$\mathrm{ICA}=$ internal carotid artery, $\mathrm{VA}=$ verterbral artery

Table 2: Aortic root diameter in two groups of females.

\begin{tabular}{llllll}
\hline \multicolumn{3}{c}{ Experimental group } & \multicolumn{2}{l}{ Control group } \\
\hline & Age & Dissection & $\begin{array}{l}\text { Aortic root } \\
\text { diameter, cm }\end{array}$ & Age & $\begin{array}{l}\text { Aortic root } \\
\text { diameter, cm }\end{array}$ \\
\hline 1. & 48 & ICA & 2.7 & 28 & 2.6 \\
2. & 29 & ICA & 2.9 & 31 & 2.8 \\
3. & 30 & ICA & 2.4 & 41 & 2.1 \\
4. & 68 & ICA & 2.7 & 49 & 3.1 \\
5. & 45 & ICA & 2.7 & 39 & 2.4 \\
6. & 35 & ICA & 2.7 & 44 & 2.6 \\
7. & 30 & VA & 3.1 & 58 & 3.1 \\
8. & 39 & VA & 2.9 & 39 & 2.6 \\
9. & 59 & VA & 3.6 & 61 & 2.7 \\
10. & & & & 29 & 2.2 \\
\hline Mean & $\mathbf{4 2 . 6}$ & & $\mathbf{2 . 8 5 6 *}$ & $\mathbf{4 1 . 9}$ & $\mathbf{2 . 6 2 0 *}$ \\
SD & $\mathbf{1 3 . 8}$ & & $\mathbf{0 . 3 4 0}$ & $\mathbf{1 1 . 4}$ & $\mathbf{0 . 3 3 3}$ \\
\hline
\end{tabular}

*Single tail $t$-test $\mathrm{p}=0.0727$

ICA = internal carotid artery, VA = verterbral artery

that cervical artery dissection may have a developmental origin appeared worth exploring and led us to test the hypothesis that cervical arterial dissections may therefore be associated with other developmental defects.

Our data reveal a positive association, only in males, between cervical artery dissection and widening of the aortic root. Although our initial data base identified 49 patients with dissection, the lack of echocardiography data limited our investigation to 20. Additionally, four of these were eliminated because they had hypertension, and we were concerned this condition may be an independent cause of aortic root enlargement. Despite this limited number of patients, the statistical correlation for males between a dissection event and the aortic root diameter was quite strong. Our hypothesis has since been confirmed in a similar case control study. ${ }^{21}$ 


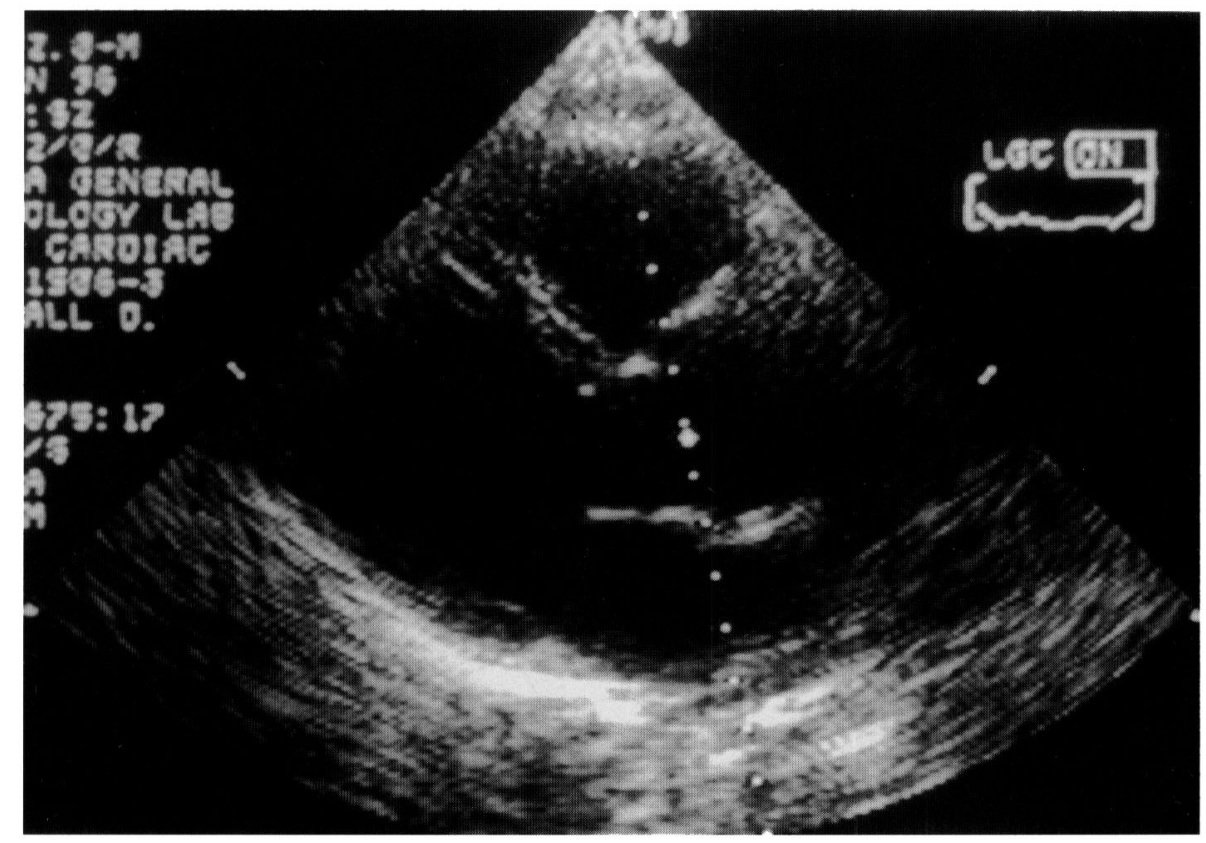

Figure 2: Parasternal long-axis echocardiographic view of a patient with aortic root dilatation. M-mode cursor is at the level of the aortic root.

The neural crest is a transient embryonal structure that gives rise to many different types of cells and contributes to the formation of diverse organs, including melanocytes, portions of the heart and the tunica media of the aortic arch and its branches. ${ }^{14,15,18}$ Experimental studies have shown that the neural crest contributes to the development of the cardiac outflow tract, ${ }^{33-37}$ and the same seems to be true in humans. ${ }^{38}$ The term "cardiac outflow tract" generally refers to the embryonal structure that functions as a sphincter at the arterial pole of the primitive heart which, at that stage, has not developed one-way valves. Subsequently, immigrating cells of the neural crest influence remodelling of the ventriculoarterial junction tissue. ${ }^{39}$ In this study, the aortic root is looked at as part of the "ventriculoarterial junction". The neural crest starts out as a group of nondifferentiated, multipotent cells that leave the neural tube immediately upon its closure. When the cells start to migrate, they do so in two directions - cranial and caudal. As they approach their definitive sites they become more and more differentiated. The cranial group of cells differentiates into ectomesenchyme and populates the pharyngeal arches. It gives rise to smooth muscle cells of the elastic arteries, fibrous tissue cells of the heart and face, pia mater and arachnoid, odontoblasts in the teeth and parts of the thymus and parathyroid glands. The caudal group does not differentiate into mesenchyme but into melanocytes of the skin, chromaffin cells of the adrenals, Schwann cells and sensory and autonomic ganglion cells. ${ }^{38}$ Thus, the cranial neural crest cells form the aortic arch, cervical arteries, carotid body, coronary arteries, cardiac outflow tract and aortopulmonary septum. ${ }^{34,35}$ More precisely, the tunica media of the aortic arch arteries is made up of neural crest cells exclusively ${ }^{40}$

Experimental models have provided a precise description of the cardiac tissues resulting from the neural crest cells. ${ }^{33}$ The ablation of different parts of the cranial neural crest of chick embryos leads to phenotypes with well defined cardiac and extra cardiac malformations. ${ }^{34,35,41}$ The presence of an intact neural crest is also necessary for the development of vascular smooth muscle cells in the aorta and coronary arteries ${ }^{42}$ Another component of the tunica media of large arteries - elastin - is also highly dependent on neural crest function. All the regions to which ectomesenchyme of cranial (cardiac) neural crest contributes are destined to become blood vessels of the elastic type. ${ }^{43}$ Disruption of the neural crest at an early stage leads to impairment in the initiation and downstream propagation of elastogenesis. ${ }^{44}$ Neural crest defects occurring later in embryogenesis affect only the spatial configuration of the elastin matrix. $^{44}$

In summary, our findings suggest that arterial dissections in the neck may in part be due to a developmental disturbance in the neural crest followed by a corresponding defect in phenotype. We suspect that the earlier the insult to the neural crest, the more severe and widespread the phenotypic defect. That may explain the rare association of dissections (cranial neural crest) with lentigines (caudal neural crest) in some families. Perhaps our findings will induce others to confirm prospectively that cervical artery dissections are a part of a wider vasculopathic syndrome.

\section{ACKNOWLEDGEMENTS}

The authors thank Dr. W.F. Morrish, Dr. S. Grahovac, Dr. R. Wee and Dr. P. Kalapos for their helpful input.

\section{REFERENCES}

1. Hart RG, Easton JD. Dissections. Stroke 1985; 16: 925-927.

2. Hart RG. Vertebral artery dissection. Neurology $1988 ; 38: 987-989$.

3. Schievink WI, Mokri B, Whisnant JP. Internal carotid artery dissection in a community: Rochester, Minnesota, 1987-1992. Stroke 1993; $24: 1678-1680$.

4. Giroud M, Fayolle $\mathrm{H}$, Andre N, et al. Incidence of internal carotid artery dissection in the community of Dijon. J Neurol Neurosurg Psychiatry 1994; 57: 1443. 
5. Mokri B. Spontaneous dissections of internal carotid arteries. Neurologist 1997; 3: 104-119.

6. Bogousslavsky J, Regli F. Ischemic stroke in adults younger than 30 years of age: cause and prognosis. Arch Neurol 1987; 44: 479-482.

7. Schievink WI, Mokri B, O'Fallon WM. Recurrent spontaneous cervical-artery dissection. N Engl J Med 1994; 330: 393-397.

8. Schievink WI, Michels VV, Piepgras DG. Neurovascular manifestations of heritable connective tissue disorders. Review. Stroke 1994; 25: 889-903.

9. Farrell MA, Gilbert JJ, Kaufmann JCE. Fatal intracranial arterial dissection: clinical pathological correlation. J Neurol Neurosurg Psychiatry 1985; 48: 111-121.

10. Chang CM, Ng HK, Leung SY, Fong KY, Yu YL. Fatal bilateral vertebral artery dissection in a patient with cystic medial necrosis. Clin Neurol Neurosurg 1991; 93-4: 309-311.

11. Ojemann RG, Fisher CM, Rich JC. Spontaneous dissecting aneurysm of the internal carotid artery. Stroke 1972; 3: 434-440.

12. Cattell MA, Hasleton PS, Anderson JC. Increased elastin content and decreased elastin concentration may be predisposing factors in dissecting aneurysms of human thoracic aorta. Cardiovasc Res 1993; 27: 176-181.

13. Bonnet J, Aumailley M, Thomas D, et al. Spontaneous coronary artery dissection: case report and evidence for a defect in collagen metabolism. Eur Heart J 1986; 7: 904-909.

14. Schievink WI, Mokri B. Familial aorto-cervicocephalic arterial dissections and congenitally bicuspid aortic valve. Stroke 1995; 26 : 1935-1940.

15. Schievink WI, Michels VV, Mokri B, Piepgras DG, Perry HO. A familial syndrome of arterial dissections with lentiginosis. $\mathrm{N}$ Engl J Med 1995; 332: 576-579.

16. Schievink WI, Mokri B, Michels VV, Piepgras DG. Familial association of intracranial aneurysms and cervical artery dissections. Stroke 1991; 22: 1426-1430.

17. Kuivaniemi H, Prockop DJ, Wu Y, et al. Exclusion of mutations in the gene for type III collagen (COL3A1) as a common cause of intracranial aneurysms or cervical artery dissections. Neurology 1993; 43: 2652-2658.

18. Schievink WI, Mokri B, Piepgras DG, Gittenberger-de Groot AC. Intracranial aneurysms and cervicocephalic arterial dissections associated with congenital heart disease. Neurosurgery 1996; 39: 685-689.

19. Henry WL, Gardin JM, Ware JH. Echocardiographic measurements in normal subjects from infancy to old age. Circulation 1980; 62: 1054-1061.

20. Shores J, Berger KR, Murphy EA, Pyeritz RE. Progression of aortic dilatation and the benefit of long term beta-andrenergic blockade in Marfan's syndrome. N Engl J Med 1994; 330: 1335-1341.

21. Tzourio C, Cohen A, Lamisse N, Biousse V, Bousser M-G. Aortic root dilatation in patients with spontaneous artery dissection. Circulation 1997; 95: 2351-2353.

22. Ambary A, Watanabe Y, Saeki N. Dissecting aneurysms of the intracranial vertebral artery. J Neurosurg 1990; 72: 183-188.

23. Sato O, Bascom JF, Logothetis J. Intracranial dissecting aneurysm. Case report. J Neurosurg 1971; 35: 483-487.

24. Endo S, Nishijima M, Nomura H, Takaku A, Okada E. A pathological study of intracranial posterior circulation dissecting aneurysms with subarachnoid haemorrhage: report of three autopsied cases and review of literature. Neurosurgery 1993; 33: 732-738.
25. Chang V, Rewcastle NB, Harwood-Nash DCF, Norman MG. Bilateral dissecting aneurysms of the internal carotid arteries in an 8year-old boy. Neurology $1975 ; 25: 573-579$.

26. Guridi J, Gallego J, Monzon F, Aguilera F. Intracerebral haemorrhage caused by transmural dissection of the anterior cerebral artery. Stroke $1993 ; 24: 1400-1402$.

27. Mizutani T. Middle cerebral artery dissecting aneurysm with persistent patent pseudolumen. J Neurosurg 1996; 84: 267-268.

28. Shimoji T, Bando K, Nakajima K, Kazufumi I. Dissecting aneurysm of the vertebral artery. Report of seven cases and angiographic findings. J Neurosurg 1984; 61: 1038-1046.

29. Hoffmann M, Sacco RL, Chan S, Mohr JP. Noninvasive detection of vertebral artery dissection. Stroke 1993; 24: 815-819.

30. Chen JL, Smith R, Keller A, Kucharczyk W. Spontaneous dissection of the vertebral artery: MR findings. Comput Assist Tomogr $1989 ; 13: 326-329$.

31. Touboul PJ, Mas JL, Bousser MG, Laplane D. Duplex scanning in extracranial vertebral artery dissection. Stroke 1988; 19: 116-121.

32. Saver JL, Easton JD, Hart RG. Dissections and trauma of cervico-cerebral arteries. In: Barnett HJM, Mohr JP, Stein BM, Yatsu FM, eds. Stroke, Pathophysiology, Diagnosis and Management, 2nd Edition. London: Churchill Livingstone, 1992: 671-688

33. Phillips MT, Kirby ML, Forbes G. Analysis of cranial neural crest distribution in the developing heart using quail-chick chimeras. Circ Res 1987; 60: 27-30.

34. Kirby ML, Turnage KL, Hays BM. Characterization of conotruncal malformations following ablation of "cardiac" neural crest. Anat $\operatorname{Rec} 1985 ; 213:$ 87-93.

35. Kirby ML, Waldo KL. Neural crest and cardiovascular patterning. Circ Res 1995; 77: 211-215.

36. Bronner-Fraser M. Origins and developmental potential of the neural crest. Exp Cell Res 1995; 218: 405-417.

37. Kirby ML, Hunt $P$, Wallis $K$, Thorogood $P$. Abnormal patterning of the aortic arch arteries does not evoke cardiac malformations. Dev Dynamics 1997; 208: 34-37.

38. Kappetein AP, Gittenberger-de Groot AC, Zwinderman AH, et al. The neural crest as a possible pathogenetic factor in coarctation of the aorta and bicuspid aortic valve. J Thorac Cardiovasc Surg 1991; 102: 830-836.

39. Ya J, Schilham NW, Clevers H, Moorman AF, Lamers WH. Animal models of congenital defects in the ventriculoarterial connection of the heart. J Molec Med 1997; 75: 551-566.

40. Kirby ML. Cardiac morphogenesis - recent research advances. Pediatr Res 1987; 21: 219-224.

41. Topouzis S, Majesky MW. Smooth muscle lineage diversity in the chick embryo. Two types of aortic smooth muscle cell differ in growth and receptor-mediated transcriptional responses to transforming growth factor-beta. Dev Biol 1996; 178: 430-445.

42. Hood LC, Rosenquist TH. Coronary artery development in the chick: origin and deployment of smooth muscle cells and the effect of neural crest ablation. Anat Rec 1992; 234: 291-300.

43. Rosenquist TH, McCoy JR, Waldo KL, Kirby ML. Origin and propagation of elastogenesis in the developing cardiovascular system. Anat Rec 1988; 221: 860-871.

44. Rosenquist TH, Beall AC, Modis L, Fishman R. Impaired elastic matrix development in the great arteries after ablation of the cardiac neural crest. Anat Rec 1990; 226: 347-359. 